Anna Réz

\title{
A Feminist Ethics of Abortion
}

\author{
In Memoriam Judith Jarvis Thomson (1929-2020)
}

\section{Introduction}

In feminist philosophy, there is a silent, but consistent recurrence of criticisms regarding the mainstream "liberal" defense of the right to abortion, ${ }^{1}$ most prominently exemplified by Judith Jarvis Thomson's seminal paper "A Defense of Abortion". ${ }^{2}$ These criticisms tackle the idea of (bodily) autonomy as an improper basis for the justification of the right to abortion (including the physical and financial availability of such medical services), and relatedly argue that Thomsonian arguments do not properly frame the discussion about abortion by ignoring the social reality in which abortions take place, and women's subjective reasons to undergo abortion emerging as a result of this social reality. Also, these feminist arguments - either explicitly or implicitly - encourage the idea (the hope, one might say) that the legal permissibility of abortion can be justified without ever taking into consideration the moral status of fetuses - a never-ending and tiresome debate, which has usually led to lost fights for the feminist camp.

In the following I would like to re-evaluate these feminist concerns and examine, in light of them, the prospects of a particularly feminist ethics of abortion. I will argue that although feminist theorists are perfectly right to say that defenses based on bodily autonomy set the wrong agenda for public discourse, thus contributing to a misleading and uninformed debate, Thomsonian arguments still have some considerable advantages, both in philosophy and in the public discourse. In particular, while Thomsonian accounts can successfully sidestep the conflict between the mother's and the fetus's rights, currently available feminist proposals can meaningfully transform, but cannot eliminate this conflict.

1 See Jaggar 1973, Markowitz 1990, Scherwin 1991, Sándor 1998.

2 Thomson 1971. 


\title{
2. Thomson
}

In order to evaluate the criticisms against liberal defenses, first, we need to go back to the beginnings. Judith Jarvis Thomson's "A Defense of Abortion" was a real game-changer: instead of continuing the ongoing debate about the moral status of fetuses, Thomson argued that abortion is morally permissible even if we grant fetuses every possible right a human adult can possess. Her central and much discussed thought experiment goes like this: ${ }^{3}$

\begin{abstract}
You wake up in the morning and find yourself back to back in bed with an unconscious violinist. A famous unconscious violinist. He has been found to have a fatal kidney ailment, and the Society of Music Lovers has canvassed all the available medical records and found that you alone have the right blood type to help. They have therefore kidnapped you, and last night the violinist's circulatory system was plugged into yours, so that your kidneys can be used to extract poisons from his blood as well as your own. The director of the hospital now tells you, "Look, we're sorry the Society of Music Lovers did this to you - we would never have permitted it if we had known. But still, they did it, and the violinist is now plugged into you. To unplug you would be to kill him. But never mind, it's only for nine months. By then he will have recovered from his ailment, and can safely be unplugged from you." ${ }^{4}$
\end{abstract}

Thomson argues that intuitively, it is clearly permissible for you to unplug yourself from the violinist - and so, by analogy, it is also morally permissible for you to refute to see your pregnancy through to its end. The main lesson to be drawn from the thought experiment is that someone's right to life does not extend to using your body in order to maintain her life, or, in Frances Kamm's formulation: "The need to have your body, and only your body, provide support in the manner of pregnancy does not confer the right to have such aid begun nor to have it continue. Nor does it give you a duty to aid." ${ }^{5}$ Thus, it is not the case that the fetus's right to life and the pregnant woman's right to bodily integrity clash, and somehow the latter trumps the former, but that the right to life is not wide enough in the first place to be able to clash with the right to bodily autonomy in these cases. Consequently, Thomson regards the sustenance of unwanted pregnancies as Good Samaritarian actions and explores what sorts of other possible

3 Thomson's central thoughts in the paper develop through a series of different thought experiments, but for some (I suppose, mostly historical) reason, only the Violinist Case received much attention. Although I find this somewhat unfortunate, in the present context, the Violinist Case will serve as a sufficient basis for analysis.

4 Thomson 1971, 48-49.

5 Kamm 1992, 22. 
reasons (e.g., a special relationship, the relative ease of helping, responsibility for giving life to the fetus) might ground the duty to refrain from abortion.

The emphasis on the right to bodily autonomy, or, in a stronger form, on the concept of bodily self-ownership is obvious (although one might wonder if there could be other possible human rights or interests the violation of which are not made permissible by the fact that the continuation of a human life depends on them). Thomson focuses exclusively on the burdens of carrying a pregnancy to its end - she makes no reference whatsoever to all the other burdens related to pregnancy: that is, the burdens of raising an(other) child. As we will soon see, this will be one of the major grounds for feminist criticism: by justifying the permissibility of abortion by referring to the (gender neutral) right to bodily autonomy, Thomson radically detaches (objective) moral permissibility from the subjective reasons that women have, when they opt for abortion.

While the consequences of pregnancy are irrelevant to Thomson's argument, the circumstances of becoming pregnant are of the utmost importance, because the intuitions which Thomson's thought experiments are meant to invoke are sensitive to these circumstances. Already the first critics of Thomson' paper raised doubts about the analogy between the Violinist Case and pregnancy, arguing that the Violinist Case might be a good analogue to pregnancies resulting from rape, but certainly inadequate if we also aim to justify abortion in the case of pregnancies resulting from consensual sex. Although both Thomson and those elaborating on her ideas went to great lengths to show that consensual sex does not create special obligations which would make abortion impermissible, there are still constant doubts about the scope of Thomson's argument and the possibility to justify the permissibility of abortion in the case of consensual sex on Thomsonian grounds. ${ }^{6}$

\section{Feminist Accounts}

What is wrong with this analysis? Despite its serious shortcomings (especially when it comes to the justification of abortion when pregnancy results from consensual sex), Thomson's account has several benefits, which should be appreciated especially by feminist authors. Beside sidestepping the most notorious problem regarding the moral status of the fetus, Thomson also makes a major dialectical turn when she claims that carrying a pregnancy to term is a Good Samaritan action (instead of a potentially overriding moral duty), the justification of which should depend on establishing some additional special obligation on part of the pregnant woman. This claim implies that by

6 See e.g. Kis 1994. 
default abortion is permissible, so the burden of proof is on the opponents of abortion to come up with a new principle. Also, Thomson makes several (although somewhat unstructured) gestures to discriminate the objective moral permissibility of abortion and women's (potentially morally "indecent") subjective reasons to undergo abortion. This, as we will shortly see, becomes a point of objection for some feminist critics - by making women's subjective reasons mostly irrelevant, Thomson ignores women's point of view and the social context, which drastically forms and limits their options to choose. But it is important to see that there's also a huge gain for feminists here: if the moral permissibility of abortion is detachable from subjective reasons and their moral character, then those anti-abortion arguments which rely on the possibility of women making potentially selfish or irresponsible choices cannot get off the ground. Finally, by relying on a supposedly universal right to bodily integrity, Thomson's argument, if successful, also establishes a universal right to abortion.

\subsection{The Social Context}

A somewhat libertarianish property right to our body, however, seems to be the wrong kind of justification for feminist defenders of abortion. What's common in the feminist proposals I'm going to investigate is the firm belief that women's right to have an abortion should be justified by making reference to the social context, in which abortions take place. This social context both reflects and reinforces the social inequalities between men and women, and limits women's autonomy and well-being in the most complex and pervasive ways. We can roughly identify three major areas related to the stages of pregnancy and motherhood, which all intensify the claim that women's right to abortion should be justified by the unequal and oppressive social environment in which (hetero)sexual interactions, pregnancy, childbearing and parenting take place. ${ }^{7}$

First, in many cases women cannot choose the timing of getting pregnant - and these occasions are not limited to clear cases of rape and incest (which are in themselves much more common than we would like to notice). ${ }^{8}$ All around the world, women face significant resistance and even the threat of partner violence, if they ask their partners to use barrier methods of contraception. ${ }^{9}$ Reliable contraception methods which do not depend on men's willingness to employ them are extremely costly, compared to

7 In the following paragraphs I will rely on the Hungarian data, where these are available. Where they are not (which is unfortunately often the case), I will use other reliable international data and study results.

8 According to the latest research of United Nations Children's Fund in 2014, one out of ten underaged girls becomes a victim of rape worldwide. According to the 2012 survey of FRA, 9 out of 100 Hungarian women have experienced sexual violence since the age of 15 .

9 See e.g. Hebling - Guimarães 2004. 
Hungarian wages and none of them is covered by National Health Insurance. Also, due to the lack of meaningful sexual education and misguided beliefs coming from pornography consumption, many girls and young women (just as boys and young men) are completely ignorant about basic biological facts of pregnancy and the efficient ways of contraception. ${ }^{10}$ Taken all these factors together, one can hardly disagree with Sally Markowitz's diagnosis: "For in a sexist society, many women simply do not believe they can control the conditions under which they have sex. And, sad to say, often they may be right." 11

Second, in the period of pregnancy and childbearing, women are subjected to a constantly growing degree of medical supervision and control, which often leads to an overcoming of women's autonomy, physical and mental abuse, unnecessary and painful medical interventions ${ }^{12}$ and, in the case of childbearing, frequent and serious traumas. ${ }^{13}$ Perfectly healthy pregnant women "only" have to be voluntarily subjected to various forms of medical examinations on a monthly basis (or more often), making them a passive medical subject of their own pregnancy. Homebirth is still "barely legal" in Hungary: doctors and other medical practitioners regularly try to discourage and humiliate women and their assistance who do not wish to be subjected to outdated policies in hospitals, while at the same time justifying unnecessary medical interventions by referring to the interests of the child to-be-born.

Third, motherhood, in contrast to fatherhood, comes with an especially high price. Just to cite a few key data: Hungarian mothers spend more than twice as much time with reproductive work (household chores and tasks related to parenting) than fathers, spending on average more than 4.5 hours a day with these tasks. ${ }^{14}$ Consequently, their share in productive (i.e., paid) work is significantly lower than that of the fathers: while $91.6 \%$ of fathers raising children under 15 are employed, this rate for women is only $61.5 \%$ (and for women raising 3 or more children it is $37.4 \%$ ). ${ }^{15}$ Mothers earn significantly less than childless women, while fathers' salaries keep rising with every child they have. ${ }^{16}$ Recently, more and more economists argue that motherhood might well be the single most important contributor to the gender pay gap, ${ }^{17}$ where the underlying processes are diverse: workplace discrimination of pregnant women and women raising

10 According to a 2016 survey of NRC (unfortunately not available online anymore), $25 \%$ of people aged 16-25 in Hungary never use any method of contraception, although a third of them are sexually active. See Rónyai 2016.

11 Markowitz 1990, 10.

12 See e. g. Savander et al. 2019.

13 For a comprehensive summary of related concerns, see Simonovic 2019 and Bowser - Hill 2010.

14 Sebők 2017, 23-24.

15 Source: KSH 2018.

16 Lovász - Cukrowska-Torzewska 2018.

17 Correll - Benard - Paik 2007. 
small children; inability to have a full time job or moving forward in rank (due to the increased amount of reproductive duties) etc. These factors very often lead to mothers' financial insecurity and/or financial dependence on their male partners, which, in turn, increases the likelihood of becoming victims of domestic violence and to long term financial disadvantages, ${ }^{18}$ e.g. lower pensions. In sum, motherhood very often drastically limits women's life opportunities and is the direct cause of harms and disadvantages which can easily lead to life-threatening situations and extreme poverty.

Once we are aware of these facts, the social import of the legality, availability and safety of abortion services becomes evident - and also, now we are in a better position to understand why some feminist authors have found the Thomsonian defense of abortion deeply unsatisfactory. If women cannot fully (or even mostly) control the conditions of getting pregnant, have to undergo several processes which undermine their bodily autonomy while they are pregnant and cannot help facing a series of serious social repercussions after being pregnant, then it seems only fair to ask to be able to decide if they want to remain pregnant. Also, in light of these facts, it seems somewhat misguided to model the choice between opting for or refraining from abortion as if it would be a decision about some bodily event, lasting for nine months. Pregnancies not only change women's life - that would most probably be true even in a completely egalitarian society -, it makes them subject to a set of diverse social harms and injustices, which all reflect and reinforce already existing gender inequalities.

However, feeling the strong moral pull of these remarks is far from having a sound ethical argument for the permissibility of abortion. Once we let the Thomsonian argument go in favor of a sociologically and ethically more adequate framework of pregnancy and motherhood, we need to face the same question again: how can women's right to avoid these social disadvantages override the fetuses' right to life? In the following, I will explore two explicitly feminist alternatives. Although the proposals show significant differences, they both agree that the ethical dilemmas surrounding abortion cannot be respectfully handled by simply applying what might be called the "only a bunch of cells" sort of reply: that is, they admit that fetuses are human beings who consequently have a serious interest in staying alive - even if they fail to specify exactly how serious this interest is.

18 On the intersections of domestic violence and financial dependency, see e.g. Conner 2013, 339. 


\subsection{Jaggar's Account}

Alison M. Jaggar's defense of abortion in "Abortion and a Woman's Right to Decide" relies on two, intuitively appealing moral principles: ${ }^{19}$

(1) A human being's right to life includes whatever means are necessary to achieve a full human life, where this presumably includes such things as nutritious food, warm human companionship, etc.

(2) Decisions should be made by those, and only by those, who are importantly affected by them.

From these two principles and the social facts which I have discussed above, the permissibility of abortion follows pretty straightforwardly. First, given that the birth of a child affects her mother's life to a significantly greater extent than anyone else's (including the father and the larger community), according to the second principle, she should be the one who decides about the continuation of her pregnancy. But this prima facie right could be outweighed by the state's duty to protect the fetus's right to life. However, given that the state constantly fails to provide the necessary means for a full human life for motherless children (as it is clearly indicated by the conditions of state institutions), it cannot claim to be, according to the first principle, the protector of fetuses' right to life. Thus, we return to the original proposal: under the current social circumstances, which basically places all of the burden of providing for the child's needs on the mother's shoulders, women are free to decide if they want to undergo abortion or not.

Although Jaggar's proposal seems much more appealing in its full length, this cannot fix the shortcomings of the argument, because neither of her principles survives scrutiny. With regard to the first one: it is far from being obvious that ordinarily (either in a legal or moral context) we understand the right to life to include any means necessary to achieve a full human life (whatever that might mean). Usually, when we talk about the right to life, what we want to grant is that people would refrain from such actions which would result in endangering another person's life. This is one of the lessons which can also be drawn from Thomson's original argument: the right to life implies duties related to not risking or taking away another person's life: it is more about refraining than actively doing something. It might well be that what we value about human life is not the sheer existence of a human being, ${ }^{20}$ but a full, flourishing human

19 Jaggar 1973, 282.

20 See Dworkin 1994. 
existence - but it is a hard and long way from here to the conclusion that the right to life means the right to have a full human life. These are obviously contestable and contested ideas. However, that does not change the fact that without providing further arguments the first principle diverges from the ordinary usage of the term importantly.

Also, there is something disturbing about the thought that by failing to give one sort of protection for children, the state lays down its right to provide any sort of protection for fetuses and children. By extending this thought we might easily reach the conclusion that once a state fails to live up to a standard, it loses its rights to try to meet them in the future. But this is not how we usually think about these matters. If we think that the state should protect the well-being of children, then it is hard to see why failing to fulfill this obligation would erase the obligation itself, instead of giving a reason to try harder. If fetuses have a right to life which includes the right to not being aborted, then the state should somehow protect this right, no matter what else it does or does not do.

Additionally, related problems arise with regard to the second principle: it is so wide and so general that it allows for countless counterexamples. For instance, following Jaggar's formulation, the state would not be entitled to prohibit parents from using violent disciplining, since they are the ones most affected by their child's behavior and also by their child-raising methods. This is clearly an unacceptable conclusion, but Jaggar's formulation does not give us any clue about how to properly set the scope of the principle.

Although Jaggar's argument in the form that it is presented is hardly acceptable, it exemplifies some features of feminist proposals, which are worthy to note. First, in a very important sense, these feminist proposals are more modest than Thomson's argument: as Jaggar explicitly claims, she only wants to establish a contingent, rather than universal right to abortion. Abortion should be permissible given that we live in a society which allocates the burdens of parenting in a radically unequal manner, and which consequently creates an interlocked set of social disadvantages for pregnant women and mothers. But, we could live in an equal society, where mothers, fathers, relatives, local communities and the state share the burden of providing for children's needs. In such a world, abortion would not necessarily be permissible - although, as both Jaggar and Markowitz emphasize, we might be unable even to imagine how such a world would look.

Second, it can already be seen how difficult it is to say anything conclusive about the conflict between the mother's and the fetus's rights in this framework. While Thomson's analogies and thought experiments successfully displayed and resolved this 
conflict, in Jaggar's case, the comparison is vague and indeterminate - we do not even know how we should begin to handle these competing claims.

Nevertheless, this inherent difficulty might also be instructive: that is, it helps drawing some lessons about the structure of a potentially successful feminist defense of abortion. Thomson's argument was essentially ethical: her argument aimed to justify the moral permissibility of abortion and consequently argued that legal regulations should track these moral insights. By contrast, the feminist defense is deeply political. By relying on the social disadvantages related to pregnancy and motherhood and on the permanent failure of societies to remedy gender inequalities, Jaggar's and (as we will soon see) Markowitz's proposals aim to establish that whatever may be true about the moral permissibility of abortion, in the present context, no one (including the state) is in a position to prohibit women to have an abortion. Now let us turn to another proposal of this kind.

\subsection{Markowitz's Account}

While Sally Markowitz's account shows many resemblances to Jaggar's, its explicit ambition is to depart even more radically from individualistic, rights and autonomy-based defenses of abortion. According to Markowitz, former defenses of abortion ignored two significant features of abortion policies. First, they did not take into account the fact that restrictive abortion policies are discriminatory: as a matter of basic human biology, they only restrict women's choices. Second, Markowitz refuses individualistic defenses of abortion in favor of analyzing the harms done by restrictive abortion policies as group harms, harming not individual women but women as an oppressed social group. ${ }^{21}$

Markowitz, consequently, presents the following principle in favor of the permissibility of abortion:

The Impermissible Sacrifice Principle: When a social group in a society is systematically oppressed by another, it is impermissible to require the oppressed group to make sacrifices that will exacerbate or perpetuate this oppression. ${ }^{22}$

21 I will not explore Markowitz's objections against autonomy-based accounts, although I find her insistence on group harms instead of individual harms clearly overstated and sometimes based on (in the feminist literature somewhat typical) hostile conceptions about the ideal of autonomy. In particular, I would insist that group harms should in principle be translated to individual harms, if they are to have any normative significance, and that these individual harms, in the case of pregnancy and motherhood clearly consist (at least partly) in violating women's autonomy. These substantial disagreements, however, will not have any direct impact on my assessment of Markowitz's proposal - this is why I mention them only in a footnote.

22 Markowitz 1990, 7 (emphasis in the original). 
The Impermissible Sacrifice Principle, contrary to Jaggar's principles, is not open to obvious counterexamples. Also, it incorporates two strong normative convictions regarding the moral permissibility of certain state policies. First, we usually find it deeply problematic if a given policy directly disadvantages people who already face severe social disadvantages in the same domain of social life. For instance, we might well object to the introduction of high consumption taxes on basic goods on the grounds that this regulation would require disproportionately great sacrifices from poor people who spend a much larger portion of their income on such basic goods. This is, I presume, a strong moral reason against such a policy - although in itself it is not necessarily an overriding one. However, we would certainly find strictly impermissible a policy which sets the consumption taxes higher for those people whose income falls below a certain level. Such a policy would not only be discriminatory, but discriminatory in the meanest way: harming those who are most harmed in the given social dimension anyway.

According to Markowitz, restrictive abortion policies do exactly this: they discriminatorily require women's sacrifices in the exact social dimension where they are already oppressed, thus actively perpetuating that very oppression. As we have previously seen, the data confirms this diagnosis. ${ }^{23}$

The principle seems sound and convincing - but how does it fare when it is confronted with the fetus's assumed right to life? Not so well, if we rely on Markowitz's own replies. After considering several, moderately promising lines of argument, Markowitz writes:

Whether or not we can weigh the disadvantage of fetuses against the oppression of women, we must realize what insisting on such a comparison does to be the debate. It narrows our focus, turning it back to the conflict between the rights of fetuses and of women (even if now this conflict is between the rights of groups than of individuals). This is certainly not to deny that fetal should be relevant to an abortion policy. But feminists must that the oppression of women should be relevant too. And it relevant that unless our society changes in deep and global anti-abortion policies, intentionally or not, will perpetuate women's oppression by men. This, then, is where feminists stand firm. ${ }^{24}$

23 The only, I would say mostly technical problem concerns the exact wording of the principle. That is, one might say that we use the word "sacrifice" here in a question-begging manner. Saying that something is a sacrifice implies that one is not obliged to do it - while what is at stake here is exactly the permissibility of choosing abortion. However, the principle might easily be rephrased to avoid this problem: we can say for instance that it is impermissible to require the oppressed group to accept otherwise avoidable burdens that will perpetuate their oppression.

24 Markowitz 1990, 12. 
This retreat to feminist strategic reasons does not add much to solving the issue. Obviously, feminists are rightly interested in avoiding the debate about the moral status of the fetus and instead focusing on those oppressive social systems which make women unwilling to give birth to an(other) child. Also, they are perfectly right in claiming that in an egalitarian society, there would be considerably fewer abortions - and that often exactly those political actors who are so keen to fight for the life of fetuses seem to be the least eager to pay attention to the social harms and inequalities which lead to abortions. But these highly important remarks do not even come close to responding to the actual concern: how should the state regulate abortion, if it wants to protect fetuses' right to life, but also wants to avoid perpetuating the oppression of women?

Given the very strong reasons to accept the Impermissible Sacrifice Principle and the major importance we attach to the right to life, this looks like a tragic moral dilem$\mathrm{ma}$ for the state in the sense that it cannot jointly fulfill both of these all things considered moral obligations. ${ }^{25}$ Obviously, the dilemma is less tragic if we admit that although fetuses have a strong interest in staying alive, this interest does not amount to the same, full-fledged right to life which we attribute to already born people. These positions already do exist, ${ }^{26}$ although they might be considered somewhat unstable when they need to be more fully specified.

Simply admitting that abortion generates tragic moral dilemmas for state regulation might seem like simply rephrasing the hopeless debate between women's rights and fetuses' rights. But this is not quite true. First of all, now the dilemma is on a political scale: it is not that women have to face irresolvable moral conflicts (that this is so would require further arguments) - it is the state which has to pursue incommensurable moral aims, which become contingently inconsistent. Second, now the conflict is not between the right of bodily self-ownership and the right to life, but between failing to protect someone's right to life, on the one hand, and discriminatorily perpetuating social oppression, on the other - a tougher choice, one would say. And third, admitting that we face a tragic moral dilemma provides a strong additional reason to avoid the dilemma by preventing it. In the present context, this would further strengthen the state's obligation to prevent unwanted pregnancies (by fighting against sexual violation $s^{27}$ and providing women with adequate knowledge and financial means for efficient contraception) and also to break down gender inequalities, which create severe harms and disadvantages for mothers.

25 See Williams 1988.

26 See recently Furedi 2016.

27 I borrow the term from Alcoff 2018. 


\section{Conclusion}

There is one serious question ahead: are we, as philosophers and feminists, overall better off if we accept some feminist proposal (as characterized in the paper) than if we simply hold on to a Thomsonian account? As philosophers, first we have to realize that the feminist proposal can still be improved and refined in several directions. And although Thomson's argument is still our best shot if we want to sidestep the conflict between the rights of pregnant women and the rights of fetuses, this elegance comes at a price: we have to accept the existence of a particularly strong universal property right to our bodies, which might be suspicious to many nowadays, and also, we have to face the recurring problems of justifying abortion in the case of consensual sex.

For active feminists aiming to influence the public discourse, a well-established feminist proposal brings about several benign consequences. First, it provides a framework where both women's subjective reasons for abortion and the social context of their choices can be adequately represented and discussed. Second, the feminist proposal shifts the moral burdens of a heavy choice from the shoulders of individual women to state policies, thus contributing to a par excellence political, instead of moralizing debate. Also, the feminist proposal, in contrast to Thomsonian accounts, does not crucially rely on the distinction between wanted versus unwanted pregnancies, but rather between pregnancies which create a complex set of social harms and disadvantages for women versus those which take place in a more just and egalitarian society.

But there are some serious obstacles here. The principal difficulty is that any version of the feminist proposal will use the systematic, unjust oppression of women as an empirical premise for their argument (Markowitz calls it the "Feminist Proviso") - a claim which is refuted in many countries (including Hungary) by the vast majority of men and women. Although referring to bodily autonomy might seem like a poor and unsatisfactory strategy for committed feminist theorists, it might well be that slogans like "Get out of my uterus!" and "My body, my choice" are in a better position to persuade masses about the impermissibility of restrictive abortion policies. ${ }^{28}$ Building a strategy which crucially relies on widely controversial premises runs a serious risk that it remains inefficient or even counter-productive.

28 As a matter of empirical observation, the data does not support the claim that consciousness about gender inequality would be the sole or even a major factor in determining people's stance on abortion. Although people who are critical about traditional gender roles are more in favor of permissive abortion policies, the same is not true in the other direction: people in Hungary are consistently strongly against restrictive abortion policies, while at the same time being highly conservative with regard to traditional gender roles. This suggests that most people have "pro-choice" reasons, which are completely independent from the acceptance of basic feminist insights. See European Values Study 2017 and Special Eurobarometer 465. 
We can only hope that we will not have to face these strategic dilemmas in the near future.

\section{Bibliography}

Alcoff, L. M. 2018. Rape and resistance. New York: John Wiley \& Sons.

Bowser, D. - K. Hill. 2010. Exploring evidence for disrespect and abuse in facility-based childbirth. Boston: Harvard School of Public Health.

Conner, D. H. 2013. "Financial freedom: Women, money, and domestic abuse." Wm. \& Mary J. Women \& L. 20: 339-97.

Correll, S. J. - S. Benard - I. Paik. 2007. "Getting a Job: Is There a Motherhood Penalty? 1." American journal of sociology 112/5: 1297-1339. DOI: 10.1086/511799.

Dworkin, R. 1994. Lifés dominion. An argument about abortion, euthanasia and individual freedom. New York: Random House.

EVS (2020): European Values Study 2017: Integrated Dataset (EVS2017). Cologne: GESIS Data Archive. [https://europeanvaluesstudy.eu/methodology-data-documentation/survey-2017/ full-release-evs2017] (2020.11.15.)

European Union Agency for Fundamental Rights. 2012. Gender-based violence against women survey dataset. [https://fra.europa.eu/en/publications-and-resources/data-and-maps/survey-data-explorer-violence-against-women-survey] (2020.11.15.)

Furedi, A. 2016. The moral case for abortion. New York: Springer.

Hebling, Eliana Maria - Isaura Rocha Figueiredo Guimarães. 2004. "Women and AIDS: gender relations and condom use with steady partners." Cadernos de Saúde Pública 20/5: 1211-18. DOI: 10.1590/S0102-311X2004000500014.

Jaggar, A. 1975. "Abortion and a Woman's Right to Decide." In Philosophy and Sex, edited by R. Baker - F. Elliston, 324-337. Buffalo: Prometheus Press.

Központi Statisztikai Hivatal. 2018. Munkavégzés és családi kötöttségek - 2018. II. negyedév. [http://www.ksh.hu/docs/hun/xftp/idoszaki/munkerohelyz/munkavegzes/index.html] (2020.11.15.)

Lovász Anna - Ewa Cukrowska-Torzewska. 2018. "A gyermekvállalás szerepe a női-férfi bérkülönbség alakulásában.” In Munkaeröpiaci tükör 2017, edited by Fazekas Károly - SzabóMorvai Ágnes, 164-166. Budapest: MTA Közgazdaság- és Regionális Tudományi Kutatóközpont Közgazdaság-tudományi Intézet.

Markowitz, S. 1990. "Abortion and feminism." Social Theory and Practice 16/1: 1-17.

Kamm, F. M. 1992. Creation and abortion: A study in moral and legal philosophy. Oxford: Oxford University Press.

Kis, J. 1994. “Abortusz: újabb érvek és ellenérvek." Café Bábel 4/11-12: 11-32. 
Rónyai, J. (2016). "Riasztó statisztika: 'Hiba, hogy nem mondjuk el a gyerekeinknek, hogyan kéne jól szexelni'.” [https://24.hu/elet-stilus/2016/09/26/riaszto-statisztika-hiba-hogy-nem-mondjuk-el-a-gyerekeinknek-hogyan-kene-jol-szexelni] (2020.11.15.)

Sándor, J. 1998. "Újabb érvek a terhességmegszakítás alkotmányosságáról." Fundamentum 2/3: $121-134$.

Savander, E. É. - M. Pänkäläinen - M. Leiman - J. Hintikka. 2019. "Implementation of Dialogical Sequence Analysis as a Case Formulation for the Assessment of Patients at a Community Mental Health Centre: Randomized Controlled Pilot Study." European Journal of Mental Health 14/2: 209-229. DOI: 10.5708/EJMH.14.2019.2.1.

Sebők, Cs. 2017. “A háztartási munkára fordított idő nemek szerinti változásai 1999-2000 és 2009-2010 között.” In Háztartási munka, önkéntes munka, láthatatlan munka I., edited by Janák Katalin - Szép Katalin - Tokaji Károlyné, 15-58. Budapest: KSH. [https://www.ksh. hu/docs/hun/xftp/idoszaki/lathatatlan/lathatatlan_munka_1.pdf] (2020.11.15.)

Sherwin, S. 1991. "Abortion through a feminist ethics lens." In Readings in Health Care Ethics, edited by Elisabeth (Boetzkes) Gedge - Wilfrid J. Waluchow, 238-48. Calgary: Broadview.

Simonovic, Dubravka. 2019. A human rights-based approach to mistreatment and violence against women in reproductive health services with a focus on childbirth and obstetric violence. UN General Assembly. [https://eipmh.com/wp-content/uploads/2019/09/UN_Res.71170.. pdf?fbclid=IwAR10wiSJybEgA6FXDJirkgeSYBIa4Vh-jOZDVdiVKG3156saegyAyQpoYo4] (2020.11.15.)

Thompson, J. J. 1971. “A Defense of Abortion.” Philosophy and public affairs 1/1: 47-66.

TNS opinion \& social. 2017. Special Eurobarometer 465: Gender Equality 2017. [https://ec. europa.eu/commfrontoffice/publicopinion/index.cfm/ResultDoc/download/ DocumentKy/80678] (2020.11.15.)

United Nations Children's Fund. 2014. Hidden in Plain Sight: A statistical analysis of violence against children. New York: UNICEF. [http://files.unicef.org/publications/files/Hidden_in_ plain_sight_statistical_analysis_EN_3_Sept_2014.pdf] (2020.11.15.)

Williams, B. 1988. "Ethical consistency.” In Essays on moral realism, edited by G. Sayre-McCord, 41-58. Ithaca, NY: Cornell University Press. 